\title{
Thoracic Splenosis
}

\section{Torasik Splenosis}

Hüseyin Fatih Sezer', Tuba Çiffçi Küsbeci², Ahmet Hamdi Ilgazlı ${ }^{3}$

\section{Abstract}

The spread of spleen tissue through different parts of the body is referred to as autotransplantation splenosis, and is an acquired and rare condition. The focal spread of splenic tissue into the thorax due to diaphragm laceration is referred to as thoracic splenosis, and may present as more than one pleural nodule in the left hemithorax. It usually occurs after a blunt trauma causing a combination of spleen injury and left diaphragmatic rupture. In the present study, we present a case of intrathoracic splenosis in an 18year-old male patient who had undergone a splenectomy 14 years earlier after suffering a gunshot wound.

Key words: Thoracic splenosis, splenectomy, trauma.

\section{Özet}

Vücudun birçok yerine dalak dokusunun yayılması ototransplantasyon splenosis olarak tanımlanır. Edinsel ve nadir bir durumdur. Diyafragma laserasyonuna bağlı olarak dalak dokusunun toraks içine fokal yayılımı torasik splenosis olarak adlandırılmaktadır. Sol hemithoraxta birden fazla plevral bazlı nodül olarak görülür. Genellikle dalak yaralanması ve sol diyafragmatik rüptür kombinasyonuna neden olan künt travma sonrasında ortaya çıkar. Çalışmamızda, 14 yıl önce ateşli silah yaralanması sonrası nedeniyle splenektomi yapılmış 18 yaşındaki erkek hastada gelişen intratorasik splenozis olgusunu sunuyoruz.

Anahtar Sözcükler: Torasik splenosis, splenektomi, travma.
'Department of Thoracic Surgery, Kocaeli University, Kocaeli, Turkey

${ }^{2}$ Yozgat State Hospital, Yozgat, Turkey

${ }^{3}$ Department of Pulmonology, Kocaeli University, Kocaeli, Turkey

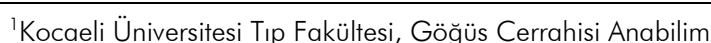
Dalı, Kocaeli

${ }^{2}$ Yozgat Şehir Hastanesi, Yozgat

${ }^{3}$ Kocaeli Üniversitesi Tıp Fakültesi, Göğüs Hastalıkları Anabilim Dalı, Kocaeli

Submitted (Başvuru tarihi): 26.07.2020 Accepted (Kabul tarihi): 21.08.2020

Correspondence (iletişim): Hüseyin Fatih Sezer, Department of Thoracic Surgery, Kocaeli University, Kocaeli, Turkey

e-mail: hfs.hfs@gmail.com 
Splenosis refers to the spread of splenic tissue as a result of lacerations to the spleen and diaphragm, and usually occurs in the peritoneal cavity. Upon passing through a ruptured diaphragmatic defect, splenic cells may implant themselves into the parietal pleura and grow in the pleural cavity (1-5). One important feature of the disease is that patients are generally asymptomatic. Splenosis appears as a peripheral nodule on chest radiography. Computed tomography (CT) imaging may suggest primary or metastatic lung cancer. If the anamnesis of the splenic injury is unknown, diagnosis may be difficult, and may require transthoracic biopsy, video-assisted thoracoscopic surgery (VATS) or thoracotomy.

\section{CASE}

An 18-year-old male presented to our clinic with leftsided abdominal pain that had started one week earlier. A thoracic CT performed at another center prior to presentation to our clinic revealed a $2.5 \mathrm{~cm}$ diameter nodular lesion in the left lower zone of the pleura and in the subpleural region. The patient had no known chronic disease, but had undergone a splenectomy and a partial excision of the left lobe of the liver 14 years earlier for the treatment of liver and spleen laceration resulting from a gunshot.

There was no smoking, and no tuberculosis or pneumonia in the patient's history. He was working as an electrician in building construction, and had no known exposure to asbestos.

A physical examination revealed fever of $37.8^{\circ} \mathrm{C}$; pulse $100 / \mathrm{min}$; blood pressure $120 / 70 \mathrm{mmHg}$; and respiratory rate $14 / \mathrm{min}$. No pathological findings were, noteworthy aside from the abdominal operation scars. Laboratory tests revealed C-reactive protein $60.94 \mathrm{mg} / \mathrm{L}$; white blood cells $13200 \mu / \mathrm{L}$; hemoglobin $13.7 \mathrm{~g} / \mathrm{dL}$; platelet count $649.8 \mu / \mathrm{L}$; erythrocyte sedimentation $20 \mathrm{~mm} /$ hour; blood urea nitrogen $11 \mathrm{mg} / \mathrm{dL}$; and creatinine 0.69 $\mathrm{mg} / \mathrm{dL}$. A chest $X$-ray revealed a $2 \mathrm{~cm}$ diameter opacity on the diaphragm in the left lower zone, as well as left sinus closure (Figure 1). The thoracic CT images were reevaluated by the radiologists of our hospital, who made the following report: "In the lower left lobe in the subpleural-juxta diaphragmatic area, multiple smooth-edged nodules, the largest of which is approximately $2 \times 4 \mathrm{~cm}$ in size, can be seen. Considering the patient's trauma history, these images are compatible with thoracic splenosis" (Figure 2). A fiberoptic bronchoscopy was performed and the respiratory tract was normal. A CT-guided tru-cut biopsy was performed on the $15 \mathrm{~mm}$ nodule in the left lung lower lobe, the pathology of which was reported as "Chronic inflamed fibroadipose tissue and benign striated muscle tissue, with no evidence in favor of malignancy in the material".

The Positron Emission Tomography (PET-BT) report read: "Nodular areas were observed in the left lung lower lobe that did not show significant metabolism in the subpleural or juxta diaphragmatic areas, but showed a slightly increased metabolism (SUVmax: 2.1). May be compatible with thoracic splenosis, as suggested by diagnostic CT. Selective spleen scintigraphy with labeled denatured erythrocytes is recommended" (Figure 3).

A selective spleen scintigraphy (SPECT) report read: "The patient, who has a history of splenectomy after splenic trauma, has multiple focal activity involvements in the left part of the abdomen and in the lower part of the left hemithorax that are evaluated to be consistent with splenosis" (Figure 4).

The patient's diagnosis was accepted as thoracic splenosis, based on radiological and nuclear medicine results. No invasive diagnostic methods were required.

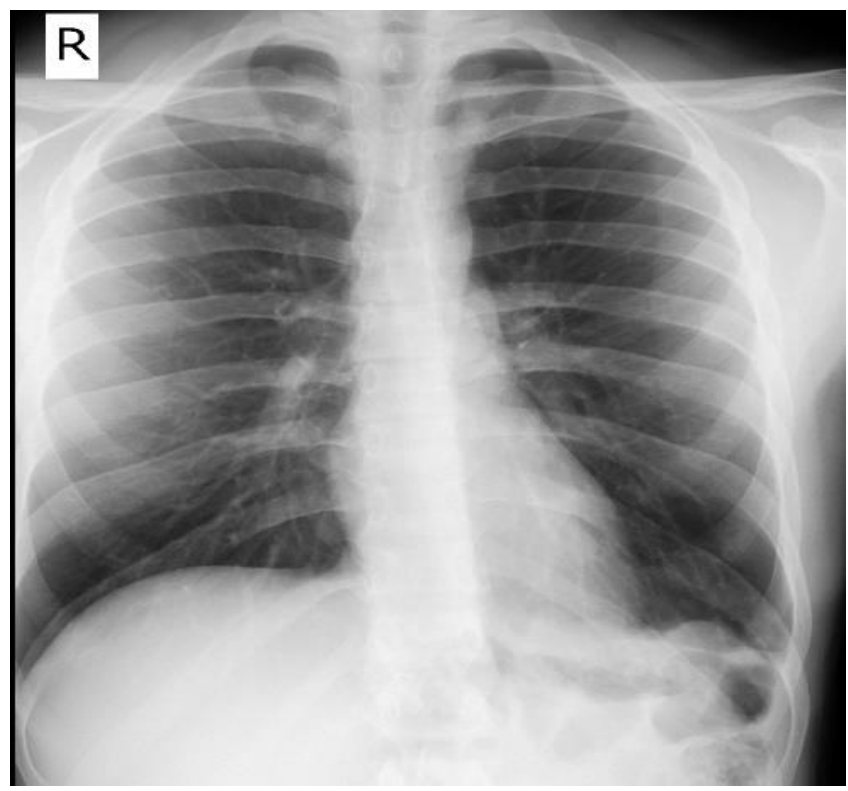

Figure 1: Chest X-ray

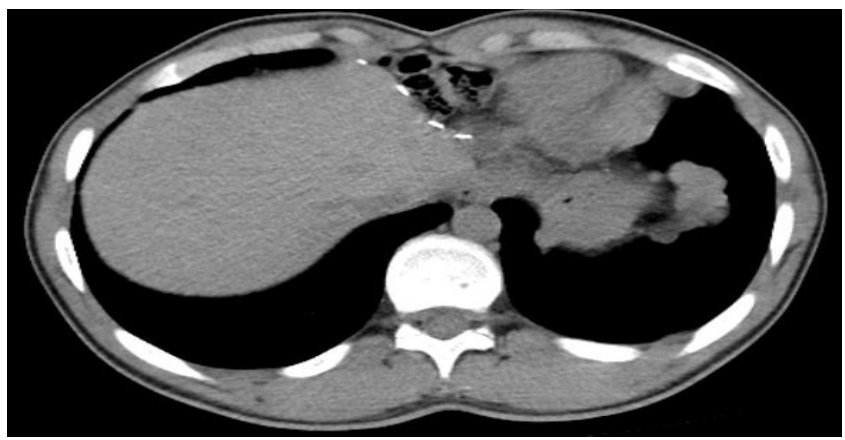

Figure 2: Thorax CT scan 


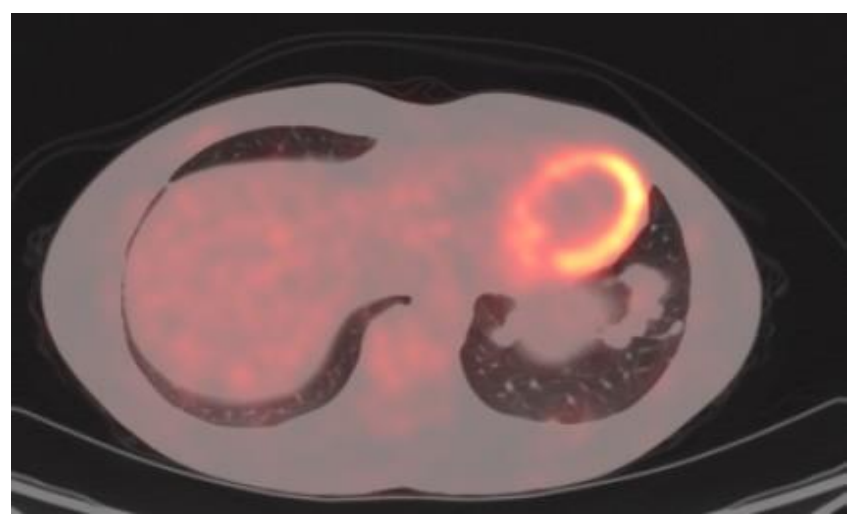

Figure 3: PET-CT scan

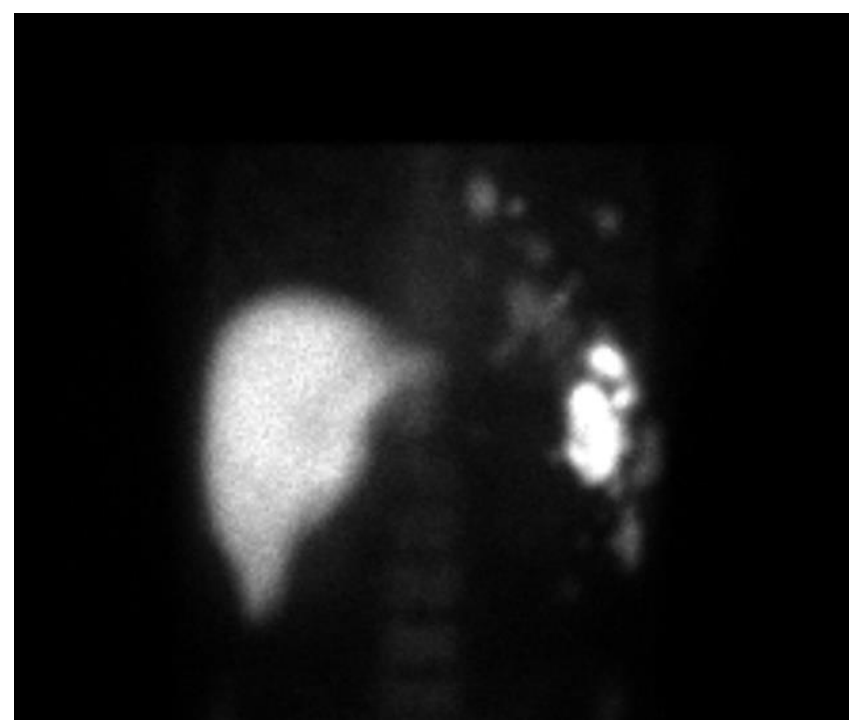

Figure 4: SPECT scan

\section{DISCUSSION}

Splenosis, defined as the autotransplantation of ectopic splenic tissue into the body after a splenic rupture or splenectomy, was first described in 1937. The main cause of splenic implantation is trauma. Although the incidence of heterotopic spleen is high in the abdominal and pelvic cavities, thoracic splenosis is a rare clinical condition that occurs in less than $0.25 \%$ of splenectomies. The splenic tissue reaches the serous surface of the pleural cavity via the damaged diaphragm. Thoracic splenosis nodules may locate in the visceral and parietal pleura, the pericardium or in interlobar fissures $(6,7)$. All cases on the topic reported in the English language in literature describe a history of splenic injury or splenectomy. Patients are generally asymptomatic. The lung parenchyma is a rare region of implantation (5).

Chest $X$-ray, thoracic CT and radionuclide scans can aid diagnosis. A detailed history is taken, and when splenosis is suspected, it can be diagnosed with a $99 \mathrm{~m}$-Technetium heat-damaged red blood cell scan, which offers high sensitivity and specificity to splenic tissue (8). Tc-99m sulfur colloid and indium-111-labeled platelets are other, less sensitive, methods.

Although Ferumoxide MRI has been used for the diagnosis of splenosis, it is reported that more research is needed for the direct comparison of nuclear studies with Ferumoxide MRI in diagnose of splenosis $(9,10)$.

For the patient in the present study, we opted for the nuclear medicine approach to diagnosis, since we were unable to achieve a significant histopathological diagnosis via a transthoracic needle biopsy. Invasive procedures such as VATS and thoracotomy can be performed when there is suspicion of malignancy for pleural-based nodules, or where required for the removal of implants in symptomatic patients with hemoptysis, cough or pleuritic chest pain $(11,12)$.

\section{CONCLUSION}

Splenosis should be kept in mind in a differential diagnosis of lesions when there is a history of splenic trauma and when masses are detected in the thorax upon radiological imaging. No surgical resection is required in asymptomatic and uncomplicated cases.

\section{CONFLICTS OF INTEREST}

None declared.

\section{AUTHOR CONTRIBUTIONS}

Concept - H.F.S., T.Ç.K., A.H.I.; Planning and Design H.F.S., T.Ç.K., A.H.I.; Supervision - H.F.S., T.Ç.K., A.H.I.; Funding - H.F.S., T.Ç.K., A.H.I.; Materials - H.F.S., T.Ç.K., A.H.I.; Data Collection and/or Processing H.F.S., T.Ç.K., A.H.I.; Analysis and/or Interpretation H.F.S., T.Ç.K., A.H.I.; Literature Review - T.S.; Writing H.F.S., T.Ç.K., A.H.I.; Critical Review - H.F.S., T.Ç.K., A.H.I.

\section{YAZAR KATKILARI}

Fikir - H.F.S., T.Ç.K., A.H.I.; Tasarım ve Dizayn - H.F.S., T.Ç.K., A.H.I.Denetleme - H.F.S., T.Ç.K., A.H.I.; Kaynaklar - H.F.S., T.Ç.K., A.H.I.; Malzemeler - H.F.S., T.Ç.K., A.H.I.; Veri Toplama ve/veya İşleme - H.F.S., T.Ç.K., A.H.I.; Analiz ve/veya Yorum - H.F.S., T.Ç.K., A.H.I.; Literatür Taraması - H.F.S., T.Ç.K., A.H.I.; Yazıyı Yazan H.F.S., T.Ç.K., A.H.I.; Eleştirel Inceleme - H.F.S., T.Ç.K., A.H.I. 


\section{REFERENCES}

1. Burvin R, Durst RY, Ben-Arieh Y, Barzilay A. Splenosis in exit gunshot wound. Br J Dermatol 1996; 135:148-50. [CrossRef]

2. Ferraz R, Miranda J, Vieira MM, Carlos Mota J. Thoracic Splenosis. Rev Port Cir Cardiotorac Vasc 2010; 17:1535.

3. Khan A, Khan S, Pillai S. Symptomatic intrathoracic splenosis more than forty years after a gunshot injury. Cureus 2019; $11:$ e5985. [CrossRef]

4. Yousem SA. Thoracic splenosis. Ann Thorac Surg 1987; 44:411-2. [CrossRef]

5. Lopes B, Almeida LR, Vicente AA, Marcellos DC, Corassa $M$, Romano RF, et al. Thoracic splenosis as a differential diagnosis of juxtapleural nodules. Respir Med Case Rep 2013; 11:1-3. [CrossRef]

6. Normand JP, Rioux M, Dumont M, Bouchard G, Letourneau $L$. Thoracic splenosis after blunt trauma: frequency and imaging findings. AJR Am J Roengenol 1993; 161: 739-41. [CrossRef]
7. Moncada R, Williams V, Fareed J, Messmore H. Thoracic splenosis. AJR Am J Roengenol 1985;144:705-6. [CrossRef]

8. Malik UF, Martin MR, Patel R, Mahmoud A. Parenchymal thoracic splenosis: history and nuclear imaging without invasive procedures may provide diagnosis. J Clin Med Res 2010; 2:180-4. [CrossRef]

9. Prosch H, Oschatz E, Pertusini E, Mostbeck G. Diagnosis of thoracic splenosis by ferumoxides-enhanced magnetic resonance imaging. J Thorac Imaging 2006; 21 (3):2357. [CrossRef]

10. Storm BL, Abbitt PL, Allen DA, Ros PR. Splenosis: superparamagnetic iron oxide-enhanced MR imaging. AJR Am J Roentgenol 1992; 159(2):333-5. [CrossRef]

11. Bugiantella W, Crusco F, Avenia N, Fabio R, Thoracic splenosis. Report of a case and review of the diagnostic workup. Ann Ital Chir 2016; 87:S2239253X16025834.

12. Gleason JB, Hadeh A, Diacovo MJ, Schroeder JR. Combined intrathoracic and subcutaneous splenosis discovered 51 years after abdominal trauma. Case Rep Pulmonol 2015; 2015:969067. [CrossRef] 